\title{
Response of prepubertal ewes primed with monensin or progesterone to administration of $\mathrm{FSH}^{*}$
}

\author{
F. P. Sumbung $\dagger$, P. Williamson and R. S. Carson $\ddagger$ \\ School of Veterinary Studies, Murdoch University, Murdoch, Western Australia 6150 and \\ $\$$ Medical Research Centre, Prince Henry's Hospital, Melbourne, Victoria 3004, Australia
}

\begin{abstract}
Summary. Prepubertal ewe lambs were treated with FSH after progesterone priming for 12 days (Group P), monensin supplementation for 14 days (Group M) or a standard diet (Group C). Serial blood samples were taken for LH and progesterone assay, and ovariectomy was performed on half of each group 38-52 h after start of treatment to assess ovarian function, follicular steroid production in vitro and the concentration of gonadotrophin binding sites in follicles. The remaining ewe lambs were ovariectomized 8 days after FSH treatment to determine whether functional corpora lutea were present.

FSH treatment was followed by a preovulatory LH surge which occurred significantly later $(P<0.05)$ and was better synchronized in ewes in Groups $\mathbf{P}$ and $\mathbf{M}$ than in those in Group C. At 13-15 h after the LH surge significantly more large follicles were present on ovaries from Group $P$ and $M$ ewes than in Group C. Follicles $>5 \mathrm{~mm}$ diameter from ewes in Groups $P$ and $M$ produced significantly less oestrogen and testosterone and more dihydrotestosterone, and had significantly more hCG binding sites, than did similar-sized follicles from Group C animals. Ovariectomy on Day 8 after the completion of FSH treatment showed that ewes in Groups $\mathrm{P}$ and $\mathrm{M}$ had significantly greater numbers of functional corpora lutea.

These results indicate that, in prepubertal ewes, progesterone priming and monensin supplementation may delay the preovulatory LH surge, allowing follicles developing after FSH treatment more time to mature before ovulation. This may result in better luteinization of ruptured follicles in these ewes, with the formation of functional corpora lutea.
\end{abstract}

\section{Introduction}

The onset of puberty in ewe lambs is heralded by an ovulation without oestrus and the formation of a short-lived corpus luteum (Foster et al., 1975). This brief elevation of progesterone concentration (progesterone priming) seems essential for the subsequent establishment of normal cyclic and oestrous activity (Foster \& Ryan, 1979). Trounson et al. (1977) showed that exogenous progesterone priming was necessary to produce functional corpora lutea in prepubertal lambs after PMSG administration.

Monensin (Eli Lilly, Sydney), a growth-promoting feed additive derived from Streptomyces cinnamonensis, has been shown to enhance ovarian responsiveness to exogenous gonadotrophins when fed to prepubertal heifers (Busmich et al., 1980). Monensin also induces puberty at a lower age and weight in beef heifers (McCartor et al., 1979). Its principal action is thought to be the

\footnotetext{
*Reprint requests to Dr P. Williamson.

†Present address: Faculty of Agricultural Science, Hasanuddin University, Ujung Pandang, South Sulawesi, Indonesia.
} 
production of higher proportions of propionate in the rumen, thus making greater amounts of usable energy available (Richardson et al., 1976).

The present study was undertaken to investigate how progesterone priming and feeding a monensin supplement affect ovarian function in prepubertal ewes.

\section{Materials and Methods}

Animals and management. Thirty prepubertal Corriedale ewes, 28-32 weeks of age with body weight of $23 \pm 2 \mathrm{~kg}$, were penned in an open-sided shed which allowed natural lighting. Experiments were performed during the breeding season. The animals were allocated randomly to 3 groups: control $(\mathrm{C})$, progesterone-primed $(\mathrm{P})$ and monensinsupplemented $(\mathrm{M})$. They received a pelleted lamb ration ( $12 \%$ protein, $51 \%$ TDN; Westfeeds, Perth) for 2 weeks before the experiments began. Following this adjustment period, Group $M$ ewes were introduced stepwise to a monensin supplement of standard ration of $15 \mathrm{mg} / \mathrm{kg}$ over 7 days. Animals in Group $\mathbf{P}$ were then injected with progesterone (Progestin; Intervet, Sydney) at the rate of $10 \mathrm{mg} /$ day for 12 days. At 14 days after the start of the full monensin supplement (Group M) and 1 day after the final progesterone injection (Group P), all animals were injected twice daily with FSH-P (Burns-Biotech, Lincoln, NE, U.S.A.) for up to 4 days, as specified below, at a daily dose rate of $4 \mathrm{mg}$ on Day $1,3 \mathrm{mg}$ on Day 2, $2 \mathrm{mg}$ on Day 3 and $1 \mathrm{mg}$ on Day 4. FSH-P is a commercial preparation refined from animal pituitary glands. It has a potency equivalent to $345 \pm 50$ (s.e.m.) $\mathrm{mg} \mathrm{NIH-FSH}$-SI4 per g and $44.4 \pm 3.0$ (s.e.m.) mg NIH-bLH-4 per g (Armstrong \& Opavsky, 1986).

Half of the ewe lambs from each group $(\mathrm{N}=5$ ) were ovariectomized about $38 \mathrm{~h}$ (Group $\mathrm{C}$ ), $48 \mathrm{~h}$ (Group $\mathrm{M}$ ) and $52 \mathrm{~h}$ (Group P) after the start of FSH treatment. These lambs had received a total dose of $7 \mathrm{mg}$ FSH over a 2-day period. Ovariectomy was performed at a time when preovulatory follicles were most likely to be present in the ovaries, as a preliminary trial using identical FSH regimens with ewes of similar age had shown that, at ovariectomy $50 \mathrm{~h}$ after the start of FSH treatment, corpora haemorrhagica were present in the ovaries of Group C animals, whereas ovulation had not occurred in Groups M and P (F. P. Sumbung, unpublished). The ewes were anaesthetized using thiopentone sodium (Pentothal; Ceva Chemicals, Sydney), the ovaries and uterus were exposed through a midline incision, and the ovaries were excised, placed in buffered saline at $4^{\circ} \mathrm{C}$ and transferred to the laboratory. Each ovary was weighed and follicles $>1 \mathrm{~mm}$ in diameter were dissected out. Follicular diameter was measured using Vernier calipers and classified as small $(<3 \mathrm{~mm})$, medium $(3-5 \mathrm{~mm})$ and large $(>5 \mathrm{~mm})$. Follicles were incubated individually in $1 \mathrm{ml}$ medium at $37^{\circ} \mathrm{C}$ for $4 \mathrm{~h}$ in multi-well tissue culture plates (Linbro, Flow Laboratories, Sydney).

The culture medium consisted of $20 \mathrm{~mm}$ minimum essential medium Eagle (Modified) with Earl's salts and Hepes buffer supplemented with $1 \%(\mathrm{v} / \mathrm{v})$ non-essential amino acids, glutamine $(200 \mathrm{mM})$, penicillin-streptomycin, fungizone (all from Flow Laboratories, Sydney) and 2.5\% fetal calf serum (CSL, Melbourne). The incubation medium was decanted and stored at $-20^{\circ} \mathrm{C}$ until assayed for steroid hormone concentrations. Follicles $>3 \mathrm{~mm}$ in diameter were then placed in assay buffer with 1.5 M-DMSO (dimethyl sulphoxide; Ajax, Melbourne) and stored in liquid nitrogen. Granulosa cells from these follicles were later used to measure the number of ${ }^{125}$ I-labelled hCG binding sites present.

The remaining ewes $(\mathrm{N}=5)$ in each group received a total dose of $10 \mathrm{mg}$ FSH-P over a 4-day period. At 8 days after the last FSH injection the ewes were ovariectomized. Ovaries were weighed and the corpora lutea dissected free and assessed as being functional or non-functional based on gross morphology and colour (Oldham \& Lindsay, 1979). This assessment was later qualified after incubating the $\mathrm{CL}$ in culture medium to measure progesterone production in vitro. After incubation the culture medium was collected and stored at $-20^{\circ} \mathrm{C}$ until assayed for progesterone.

Hormone assays. Daily blood samples for LH measurement were obtained from all groups for 10 days immediately before the FSH treatment. Jugular blood samples were obtained at 6-h intervals from the start of FSH treatment from those ewes ovariectomized soon after the FSH treatment, while daily bleeding continued in the groups ovariectomized 8 days after FSH injections, to measure progesterone concentrations.

Circulating concentrations of $\mathrm{LH}$ were determined in triplicate using a double-antibody RIA identical to that described by Martin et al. (1980). The antibody (UWA-3B), raised in rabbits against highly purified pituitary LH (NIH-LH-S1), was used at an initial dilution of 1:150000. Antibody cross-reactivity was less than $1 \%$ for prolactin, FSH and growth hormone, and $4.6 \%$ for thyroid stimulating hormone (Martin et al., 1980). The pituitary LH preparation for both standard and iodinated tracer was NIH-LH-SI, biopotency of $2.5 \mathrm{IU} / \mathrm{mg}$ (M. Jutisz, College de France, Paris).

The concentration of progesterone in duplicate samples of culture medium was assayed using a solid-phase microtitre plate enzyme immunoassay (EIA) (Munro \& Stabenfeldt, 1984) with assay constituents supplied from their laboratory. The standard curve was prepared in culture medium with standards ranging from 0 to $3.2 \mathrm{ng} / \mathrm{well}$.

The concentrations of testosterone, dihydrotestosterone (DHT) and oestradiol in culture medium were determined after extraction of duplicate samples over celite columns. The preparation of celite columns for the chromatographic separation of the steroids was identical to that described by Horgan \& Riley (1974). The fractionation of the steroids and solvent compositions used for the elution followed the method of McNatty et al. (1979). Recoveries of ${ }^{3} \mathrm{H}$-labelled progesterone, DHT, testosterone and oestradiol were $88 \%, 80 \%, 85 \%$ and $88 \%$ respectively. Testosterone and DHT were assayed using the techniques described by McNatty et al. (1976) with an antibody (Cox 457) raised in sheep against testosterone-3-CMO-BSA conjugate (kindly provided by $\mathrm{Dr}$ R. I. Cox, CSIRO, Blacktown, NSW) at an initial dilution of 1:40000. The radioactive steroids used as tracer were $[1,2,6,7-$ 
Table 1. Hormone assay quality control data

\begin{tabular}{|c|c|c|c|c|}
\hline Assay & Sensitivity & $\begin{array}{l}\text { Intra-assay } \\
\text { coefficient } \\
\text { of variation }\end{array}$ & $\begin{array}{l}\text { Inter-assay } \\
\text { coefficient } \\
\text { of variation }\end{array}$ & $\begin{array}{l}\text { Non- } \\
\text { specific } \\
\text { binding }\end{array}$ \\
\hline \multicolumn{5}{|l|}{ RIA } \\
\hline LH & $0.7 \mathrm{ng} / \mathrm{ml}$ & $5 \cdot 1 \%$ & $8 \cdot 4 \%$ & $<4 \%$ \\
\hline Testosterone & $78 \mathrm{pg} /$ tube & $4 \cdot 6 \%$ & $8.6 \%$ & $2 \cdot 1 \%$ \\
\hline DHT & $10.4 \mathrm{pg} /$ tube & $5.8 \%$ & $12.6 \%$ & $3 \cdot 0 \%$ \\
\hline Oestradiol-17 $\beta$ & $12.5 \mathrm{pg} /$ tube & $4.0 \%$ & $15 \cdot 3 \%$ & $<4.0 \%$ \\
\hline \multicolumn{5}{|l|}{ EIA } \\
\hline Progesterone & $38 \mathrm{pg} / \mathrm{ml}$ & $4 \cdot 4 \%$ & $6 \cdot 6 \%$ & $<3 \%$ \\
\hline
\end{tabular}

${ }^{3} \mathrm{H}$ testosterone (sp.act. $107 \mathrm{Ci} / \mathrm{mm}$ ), $\left[1,2,4,5,6,7-{ }^{3} \mathrm{H}\right]$ dihydrotestosterone (sp.act. $123 \mathrm{Ci} / \mathrm{mm}$ ) (New England Nuclear, Boston, MA, U.S.A.). Compared to testosterone, the cross-reactions of the antibody were DHT $98 \%$, progesterone, oestradiol-17 $\beta$, oestrone, cortisol and androstenedione $<1 \%$.

Oestradiol was assayed using antibody and techniques described by McNatty et al. (1976) and tracer was [2,4,6,7${ }^{3} \mathrm{H}$ joestradiol-173 (sp.act. 92-104 Ci/mm: New England Nuclear). The intra-assay and inter-assay coefficients of variation for these assays, and the non-specific binding are listed in Table 1.

Determination of ${ }^{125}$ I-labelled $h C G$ binding to granulosa cells in vitro. Collections of granulosa cells and ${ }^{125}$ I-labelled hCG receptor studies were undertaken using the methods described by Webb \& England (1982a) and Atkinson et al. (1986). Pooled membrane preparations of 50, 100 and $200 \mu \mathrm{l}(100 \mu \mathrm{l}$ contained $\sim 250000$ cells) were used to establish the optimal assay conditions. Radiodinated hCG, with a specific activity of $34 \mu \mathrm{Ci} / \mu \mathrm{g} \mathrm{hCG}$ and an active fraction of $70 \%$, was provided by Dr D. Robertson (Monash University, Melbourne). The optimum specific binding of ${ }^{125} \mathrm{I}$-labelled hCG to the granulosa cell preparation was obtained at $25^{\circ} \mathrm{C}$ for $6 \mathrm{~h}$. The binding capacity of the follicles was expressed as c.p.m. hCG bound per $10^{6}$ cells.

Statistical analysis. A log-logit transformation was applied to the standard curves of the LH assay before hormone concentrations were computed (Rodbard, 1974). Steroid concentrations were read from the untransformed standard curves. All steroid data except plasma progesterone were logarithmically transformed (natural log) to reduce within-group variations before comparisons were made (Tsonis et al., 1983). The means together with the standard errors of the means (s.e.m.) are presented as retransformed arithmetic means. All hormone data and ovarian characteristics data were subjected to analysis of variance (ANOVA) and Tukey's HSD procedures (Nie et al., 1975). The differences between groups in the mean interval from start of FSH treatment and to the occurrence of an LH peak was analysed using Student's $t$ test (Snedecor \& Cochran, 1967).

\section{Results}

\section{LH concentrations in peripheral plasma}

Plasma LH concentrations measured in daily blood samples taken over the 10 days preceding FSH administration were all below $4 \mathrm{ng} / \mathrm{ml}$, except in one animal (No. 83), which had significantly higher concentrations of $\mathrm{LH}$ in all samples taken during progesterone treatments $(6.5-14 \mathrm{ng} / \mathrm{ml}$, $P<0.05)$. In all other ewe lambs a sharp increase occurred in plasma $\mathrm{LH}$ concentrations during FSH administration with peak concentrations of $9-60 \mathrm{ng} / \mathrm{ml}$. There were marked differences between the groups in the degree of synchrony of the LH surges, and in the interval between the start of FSH treatment and the LH surge (Fig. 1). In Group C, LH surges were detected in individual ewes at intervals ranging from 12 to $36 \mathrm{~h}(22.8 \pm 4.8 \mathrm{~h}$, mean \pm s.e.m. $)$ after the initiation of FSH treatment, whereas in Group P the LH surge was later $(39.0 \pm 1.7 \mathrm{~h})$, with tighter synchronization $(36-42 \mathrm{~h})$. Ewes in Group $M$ showed an intermediate LH response, surges generally being later $(34.5 \pm 2 \cdot 2 \mathrm{~h})$ than in ewe lambs of Group $\mathrm{C}$ but with less synchrony than in animals of Group P. Ewes in Groups $P$ and $M$ had significantly longer $(P<0.05)$ mean intervals than did Group C ewes between the start of FSH treatment and the occurrence of peak LH concentrations. In addition, the mean maximum plasma LH concentrations during the LH surge were higher in Groups $P$ and $M$ ewes than in Group C ewes $(40 \cdot 8 \pm 5 \cdot 6,41 \cdot 3 \pm 5 \cdot 4,20 \cdot 9 \pm 6 \cdot 4 \mathrm{ng} / \mathrm{ml}$ for Groups $\mathrm{P}, \mathrm{M}$ and $\mathrm{C}$, respectively; $P<0.05$ ). 

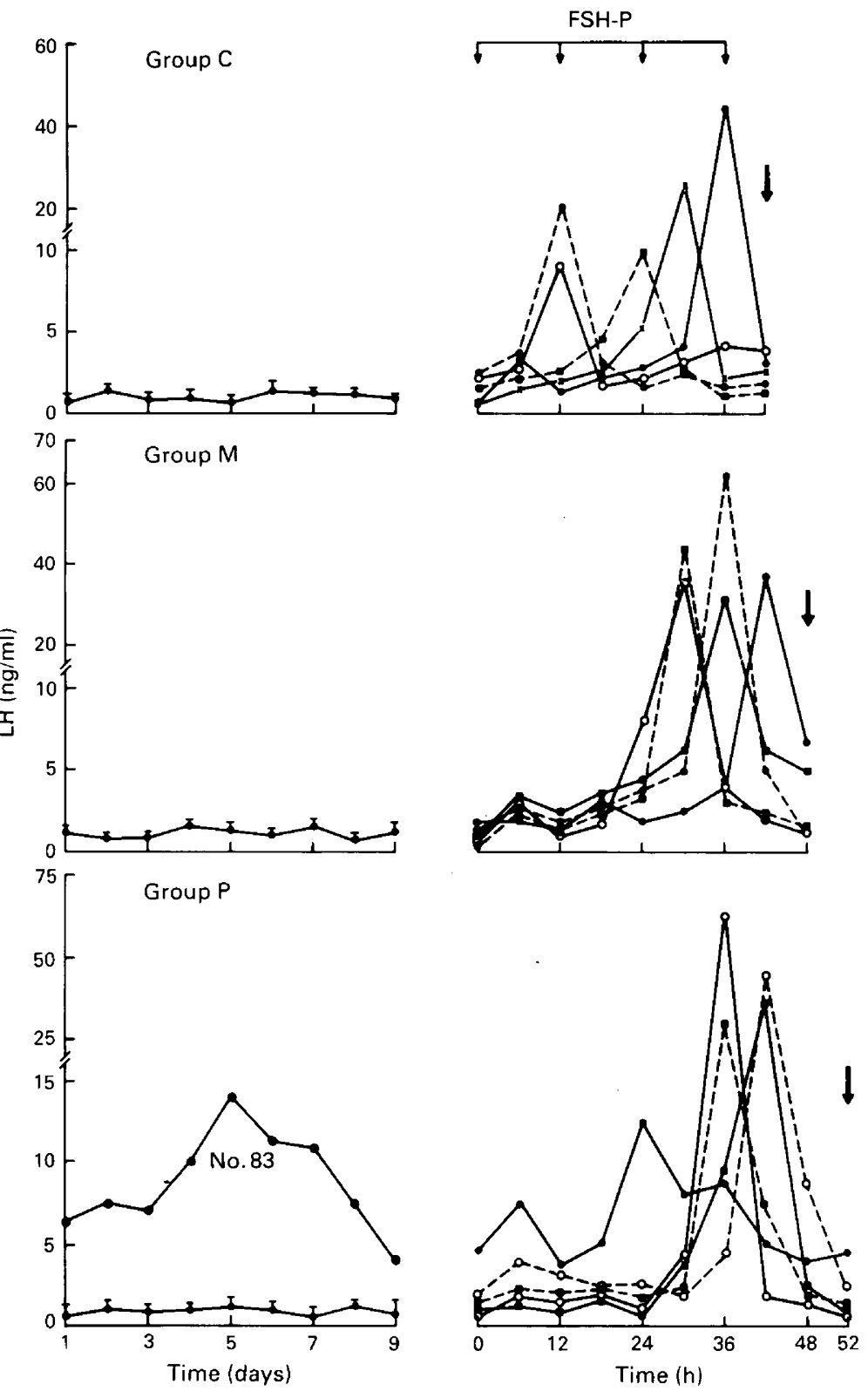

Fig. 1. Plasma LH concentrations in ewes in Groups $C$ (control), $M$ (monensin supplemented) and $\mathrm{P}$ (progesterone primed) before and during the administration of FSH. The dark arrows indicate the time of ovariectomy in each group relative to the start of FSH treatment. The mean values for each group, with the s.e. (vertical bars), are presented for sampling times before the FSH treatment, and values for individual animals are presented during FSH treatment $(\mathrm{N}=5$ for Groups $\mathrm{C}$ and $\mathrm{M}, \mathrm{N}=4$ for Group P).

\section{Animals ovariectomized at 38-52 h after start of FSH treatment}

The mean interval between the LH surge and ovariectomy, calculated retrospectively, was around 13-15 h in each group (Group C, 15.2 h; Group M, 13.5 h; Group P, 13.0 h), although the interval was less constant in Group $\mathrm{C}$ ewes. 
Table 2. Mean ovarian weight and number of follicles in ovaries from control (Group C), progesterone-primed (Group P) and monensin-supplemented (Group M) lambs ovariectomized at 38,52 and $48 \mathrm{~h}$ respectively after start of FSH treatment

\begin{tabular}{lccc}
\hline & \multicolumn{3}{c}{ Group } \\
\cline { 2 - 4 } & $\mathrm{C}($ control, $\mathrm{N}=5)$ & P (progesterone, N =4) & $\mathrm{M}$ (monensin, $\mathrm{N}=5$ ) \\
\hline Ovarian wt (mg) & $1214 \pm 113^{\mathrm{a}}$ & $2305 \pm 559^{\mathrm{b}}$ & $1218 \pm 123^{\mathrm{a}}$ \\
No of follicles: & & & \\
$<3 \mathrm{~mm}$ & $11 \cdot 1 \pm 2 \cdot 1^{\mathrm{a}}$ & $9 \cdot 0 \pm 1 \cdot 9^{\mathrm{a}}$ & $8 \cdot 1 \pm 1 \cdot 8^{\mathrm{a}}$ \\
$3 \cdots 5 \mathrm{~mm}$ & $6 \cdot 3 \pm 1 \cdot 1^{\mathrm{a}}$ & $6 \cdot 1 \pm 1 \cdot 3^{\mathrm{a}}$ & $4 \cdot 2 \pm 1 \cdot 3^{\mathrm{b}}$ \\
$>5 \mathrm{~mm}$ & $1 \cdot 9 \pm 0 \cdot 4^{\mathrm{a}}$ & $5 \cdot 7 \pm 0 \cdot 6^{\mathrm{b}}$ & $4 \cdot 6 \pm 0 \cdot 8^{\mathrm{b}}$ \\
Largest (mm) & $6 \cdot 5$ & $8 \cdot 5$ & $7 \cdot 0$ \\
\hline
\end{tabular}

Values are mean \pm s.e.m.

Values in the same row with different superscripts differ significantly $(P<0.05)$.

Table 3. In-vitro follicular steroid production $(\mathrm{ng} / \mathrm{ml})$ per $4 \mathrm{~h}$ by follicles dissected from ewe lambs $38 \mathrm{~h}$ (Group C), $48 \mathrm{~h}$ (Group M) and $52 \mathrm{~h}$ (Group P) after start of FSH treatment

\begin{tabular}{|c|c|c|c|c|}
\hline $\begin{array}{l}\text { Follicle } \\
\text { diam. } \\
(\mathrm{mm})\end{array}$ & Hormone & Group C & Group P & Group M \\
\hline $3-5$ & $\begin{array}{c}\text { T } \\
\text { DHT } \\
\text { E } \\
\text { P }\end{array}$ & $\begin{array}{l}14 \cdot 31 \pm 2 \cdot 14^{\mathrm{a}} \\
0.12 \pm 0.001^{\mathrm{a}} \\
3.31 \pm 0.03^{\mathrm{a}} \\
0.58 \pm 0.01^{\mathrm{a}}\end{array}$ & $\begin{array}{l}7.59 \pm 0.93^{\mathrm{ab}} \\
0.46 \pm 0.01^{\mathrm{b}} \\
1.24 \pm 0.02^{\mathrm{ab}} \\
0.65 \pm 0.01^{\mathrm{a}}\end{array}$ & $\begin{array}{l}3.22 \pm 0.41^{\mathrm{b}} \\
0.41 \pm 0.01^{\mathrm{b}} \\
0.71 \pm 0.02^{\mathrm{b}} \\
0.85 \pm 0.01^{\mathrm{a}}\end{array}$ \\
\hline$>5$ & $\begin{array}{c}\mathrm{T} \\
\mathrm{DHT} \\
\mathrm{E}_{2} \\
\mathrm{P}\end{array}$ & $\begin{array}{l}17.55 \pm 2.7^{\mathrm{a}} \\
0.16 \pm 0.001^{\mathrm{a}} \\
5.93 \pm 0.68^{\mathrm{a}} \\
1.57 \pm 0.03^{\mathrm{a}}\end{array}$ & $\begin{array}{l}5 \cdot 14 \pm 0 \cdot 64^{\mathrm{b}} \\
0 \cdot 46 \pm 0 \cdot 01^{\mathrm{b}} \\
2 \cdot 19 \pm 0 \cdot 06^{\mathrm{b}} \\
13 \cdot 3 \pm 3 \cdot 5^{\mathrm{b}}\end{array}$ & $\begin{array}{l}5.69 \pm 0.80^{\mathrm{b}} \\
0.47 \pm 0.01^{\mathrm{b}} \\
1 \cdot 78 \pm 0.04^{\mathrm{b}} \\
2.23 \pm 0.04^{\mathrm{a}}\end{array}$ \\
\hline
\end{tabular}

Values are mean \pm s.e.m. for follicles from 10 ovaries in each of Groups $P$ and $M$ and from 8 ovaries in Group $C$.

Values within the same row with different superscripts differ significantly $(P<0.05)$.

\section{Ovarian morphology}

The mean ovarian weight and the numbers of different sized follicles dissected from the ovaries are presented in Table 2. Corpora lutea were not present in any of the ovaries taken from the ewes. The ovarian weight in Group $\mathrm{P}$ ewes was significantly higher $(P<0.05)$ than in Groups $\mathrm{C}$ or $\mathbf{M}$. There was no significant difference in the number of follicles $<3 \mathrm{~mm}$ in diameter between the groups. The number of follicles $3-5 \mathrm{~mm}$ in diameter was significantly higher in ovaries from Groups $\mathrm{C}$ and $\mathrm{P}$ than in those from Group $\mathrm{M}$ animals $(P<0.05)$. However, there were significantly more $(P<0.05)$ follicles $>5 \mathrm{~mm}$ in diameter in Groups $\mathrm{P}$ and $\mathrm{M}$ than in Group $\mathrm{C}$.

The ovaries from Lamb 83 (Group P), which had irregular LH patterns, were hypoplastic, measuring $<5 \mathrm{~mm}$ in diameter, and having no follicles $>1 \mathrm{~mm}$ present in the stroma. Results from this ewe were excluded from calculations of Group $P$ mean values.

\section{In-vitro production of steroids by incubated follicles}

In-vitro testosterone and oestradiol production by follicles $3-5 \mathrm{~mm}$ and $>5 \mathrm{~mm}$ in diameter was higher in Group $C$ than in Groups P or $M$ (Table 3). With follicles $>5 \mathrm{~mm}$ in diameter this 
Table 4. Binding of ${ }^{125} \mathrm{I}$-labelled hCG (c.p.m./ $10^{6}$ cells) to granulosa cells of follicles from ewe lambs in Groups $\mathrm{C}, \mathrm{P}$, and $\mathrm{M}$

\begin{tabular}{lrc}
\hline & \multicolumn{2}{c}{ Follicle size } \\
\cline { 2 - 3 } \multicolumn{1}{c}{ Group } & \multicolumn{1}{c}{$3-5 \mathrm{~mm}$} & $>5 \mathrm{~mm}$ \\
\hline $\mathrm{C}$ (control) & $665 \pm 116^{\mathrm{a}}(13)$ & $1534 \pm 175^{\mathrm{a}}(8)$ \\
$\mathrm{P}$ (progesterone) & $1226 \pm 138^{\mathrm{b}}(14)$ & $3105 \pm 310^{\mathrm{b}}(13)$ \\
$\mathrm{M}$ (monensin) & $1498 \pm 156^{\mathrm{b}}(13)$ & $2983 \pm 504^{\mathrm{b}}(11)$ \\
\hline
\end{tabular}

Values are mean \pm s.e.m. for the no. of follicles indicated in parentheses.

Values in the same column with different superscripts differ significantly $(P<0.05)$.

Table 5. Mean \pm s.e.m. ovarian weight and number of corpora lutea in ewe lambs 8 days after FSH challenge

\begin{tabular}{|c|c|c|c|}
\hline \multirow[b]{2}{*}{ Group } & \multirow{2}{*}{$\begin{array}{c}\text { Ovarian wt } \\
\text { (mg) }\end{array}$} & \multicolumn{2}{|c|}{ Corpora lutea } \\
\hline & & Total & Functional \\
\hline $\mathrm{C}$ (control, $\mathrm{N}=5$ ) & $1304^{a} \pm 124$ & $2 \cdot 6^{\mathrm{a}}$ & $0 \cdot 4^{\mathrm{a}}$ \\
\hline $\mathrm{P}$ (progesterone, $\mathrm{N}=5$ ) & $2258^{\mathrm{b}} \pm 507$ & $3 \cdot 2^{\mathrm{a}}$ & $3 \cdot 2^{b}$ \\
\hline $\mathrm{M}$ (monensin, $\mathrm{N}=5$ ) & $2260^{b} \pm 498$ & $4 \cdot 2^{\mathrm{a}}$ & $3 \cdot 4^{b}$ \\
\hline
\end{tabular}

Values in the same column with different superscripts differ signifcantly $(P<0 \cdot 05)$.

difference was significant $(P<0.05)$. In contrast, DHT production by all incubated follicles from Groups $\mathrm{P}$ and $\mathrm{M}$ was significantly greater than by follicles from Group $\mathrm{C}$ ewes. The incubation medium from follicles $>5 \mathrm{~mm}$ in diameter from Group $P$ ewes had significantly more progesterone than did medium from follicles of this size in Groups $\mathrm{C}$ and $\mathbf{M}$.

\section{${ }^{125}$ I-labelled hCG binding sites on the granulosa cells}

The numbers of follicles $>3 \mathrm{~mm}$ in diameter from which granulosa cells were obtained for this analysis were 21,24 and 27 from ewes in Groups C, M and P, respectively. The mean binding of ${ }^{125}$ I-labelled hCG to granulosa cells is presented in Table 4 . There was a significantly higher $(P<0.05)$ c.p.m. of ${ }^{125}$ I-labelled hCG bound per $10^{6}$ granulosa cells from follicles in Groups $P$ and $M$ than from those in Group $C$. The numbers of follicles which had detectable binding sites in Group $\mathrm{C}, \mathrm{M}$ and $\mathrm{P}$ were 14,20 and 24 respectively. The larger the follicle the greater was the amount of ${ }^{125}$ I-labelled hCG bound per $10^{6}$ granulosa cells, irrespective of group $(P<0.05)$.

\section{Animals ovariectomized 8 days after start of FSH treatment}

Plasma progesterone concentrations increased in all groups after the last $\mathrm{FSH}$ injection, from a mean value of $0.3 \mathrm{ng} / \mathrm{ml}$ on the last day of FSH treatment to $1.5 \mathrm{ng} / \mathrm{ml} 3$ days later. Lambs with morphologically functional CL at ovariectomy on Day 8 (2, 5 and 4 animals in Groups $C, P$ and $\mathbf{M}$ respectively) showed a steady increase in plasma progesterone concentration, reaching a plateau of $2.02 \pm 0.20 \mathrm{ng} / \mathrm{ml}$ between Day 3 and ovariectomy. In contrast, lambs bearing non-functional CL at ovariectomy showed an initial increase in plasma progesterone concentrations, but concentrations fell after Day 3 and stayed low $(0.22 \pm 0.02 \mathrm{ng} / \mathrm{ml})$ from Day 4 until ovariectomy. 
The ovaries from ewes in Groups $\mathrm{P}$ and $\mathrm{M}$ were significantly heavier $(P<0.05)$ than those from Group $C$ ewes (Table 5). The CL classified as functional on morphology produced significantly more progesterone during in-vitro incubation than did non-functional CL $(643.6 \pm 72$ and $30.25 \pm 6.7 \mathrm{ng} / \mathrm{ml})$. While there was no difference in the number of CL between groups, ewes in Group $\mathrm{M}$ and Group $\mathrm{P}$ had significantly more functional $\mathrm{CL}$ than did ewes in Group $\mathrm{C}(P<0.05)$ at the time of ovariectomy.

\section{Discussion}

The administration of exogenous FSH to ewe lambs in the control and both experimental groups in this study resulted in a sharp increase in plasma LH concentrations, similar to the rise seen during the preovulatory LH surge in mature ewes (Hauger et al., 1977; Baird, 1978). The magnitude of this LH surge was significantly greater in the ewes in Groups $\mathbf{P}$ and $\mathbf{M}$ compared to those in Group C. Group $C$ ewes also had a significantly $(P<0.05)$ shorter interval between the start of FSH treatment and the LH surge, especially in comparison with ewes primed with progesterone (Group P). The LH peak in the progesterone-primed ewe lambs occurred at around $38 \mathrm{~h}$ after the start of FSH injections, a similar interval to that recorded in adult ewes given GnRH (Haresign et al., 1983) and progesterone-primed seasonally anoestrous ewes given LHRH (McNatty et al., 1981). The interval from the start of the FSH treatment to the LH surge recorded in control ewes in the present study could therefore be considered short compared to that measured in mature or progesterone-primed ewes. Earlier studies have shown that, if maturing follicles are exposed to a preovulatory LH surge which is too low in magnitude (Channing, 1978; McNatty et al., 1981), or is too brief (Haresign et al., 1983), the subsequent ovulation results in the formation of non-functional or short-lived CL. In the present study the ewes in both treatment groups (i.e. with a later LH peak of greater magnitude), had significantly more functional CL in their ovaries 8 days after FSH treatment than did the control ewes. Progesterone priming and monensin supplementation may therefore have exerted their effect, at least in part, by delaying, synchronizing and magnifying the LH surge which followed FSH administration. This probably allowed the developing follicles in these ewe groups sufficient time for proper growth and maturation before ovulation and luteinization. Further evidence for this effect is provided by the marked superiority in the ability of mature, preovulatory follicles from the ewes in Groups $\mathbf{P}$ and $\mathbf{M}$ to synthesize DHT in vitro, compared to those from Group $\mathrm{C}$ ewes. In addition, a far greater number of gonadotrophin binding sites were present on granulosa cells of follicles from Groups $\mathrm{P}$ and $\mathrm{M}$ at ovariectomy. The interval between the $\mathrm{LH}$ surge and ovariectomy averaged around $13-15 \mathrm{~h}$ in each group. Therefore, ovariectomizing the control ewes earlier after FSH treatment than the other two groups provided similar preovulatory (after LH surge) ovaries from each group for examination, as Cumming et al. (1971) have shown that the interval between the LH surge and ovulation is relatively constant.

Testosterone and oestradiol concentrations were low in incubation medium from follicles of ewes in Groups $\mathbf{P}$ and $\mathbf{M}$, whereas DHT concentrations were high. This indicates that the follicles had responded to the LH surge with a shutdown of their aromatase and C17-20 lyase systems, a normal sequel to the LH surge in mature, preovulatory follicles in cyclic ewes (Baird et al., 1980). In contrast, testosterone and oestradiol concentrations were high and DHT low in incubation medium from follicles of Group $\mathrm{C}$ ewes, indicating that these systems were still active about $15 \mathrm{~h}$ after the LH surge. Follicles from Group C ewes had not responded normally to the LH surge, perhaps because of their immaturity at the time of the surge or to the lower magnitude of the LH surge measured in this group.

The increase in the binding of ${ }^{125} \mathrm{I}$-labelled hCG to granulosa cells with the increase in follicle diameter in all ewe groups in the present study is in agreement with the findings of Carson et al. (1979), and indicates that normal development of follicles was occurring. The higher binding to granulosa cells in follicles of similar size in Group $\mathrm{P}$ and $\mathrm{M}$ ewes compared with Group $\mathrm{C}$ ewes 
again indicates that more of the follicles in the treatment groups were mature at the time of the LH surge. Although the follicles in this experiment were explanted after the peak of the $\mathrm{LH}$ surge, ${ }^{125}$ I-labelled hCG binding can probably still be used for comparison between the groups, as Webb \& England (1982b) have shown that ovulatory follicles still have significantly more ${ }^{125}$ I-labelled hCG bound to granulosa cells than do non-ovulatory follicles up to at least $12 \mathrm{~h}$ after the LH surge.

At ovariectomy before ovulation, ovaries from ewes in Groups $\mathbf{P}$ and $\mathbf{M}$ had significantly more follicles $>5 \mathrm{~mm}$ in diameter than did ovaries from Group $\mathrm{C}$ ewes. Despite this difference in the number of large follicles, similar numbers of ovulations occurred in all groups, as indicated by the mean number of CL present in the ovaries at 8 days. It is likely that only the most mature of the follicles in the ewes in Groups $P$ and $M$ ovulated, giving rise to the significantly greater numbers of functional CL present in these groups at Day 8 compared with ovaries from Group C ewes.

Factors that determine whether the follicles will ovulate and form a normal CL are adequate size, increase in oestradiol production and the presence of gonadotrophin binding sites in follicular cells (England et al., 1981). The possible mechanism by which progesterone priming facilitates the formation of normal CL in ewe lambs has not been examined. Bindon et al. (1979) postulated that progesterone priming may delay the LH surge by lowering the sensitivity of the hypothalamuspituitary axis to oestradiol, thereby ensuring the formation of normal CL after ovulation. This hypothesis receives some support from the present experimental results, as the delayed LH surge in the progesterone-primed ewes appeared to allow ovarian follicles more time to mature before ovulation and luteinization, resulting in the formation of functional CL. Alternatively, progesterone may act directly at the ovarian level, leading to earlier maturation of follicles, as it has been observed that the injection of progesterone into the ovary stimulates a greater development of follicles in anoestrous ewes treated with FSH (Harned \& Casida, 1971).

Monensin supplementation in feed also appeared to exert a similar effect, delaying and amplifying the LH surge in FSH-treated ewes, leading to the formation of functional CL at the subsequent ovulation. It has been suggested for beef heifers that the alteration of ruminal fermentation by dietary monensin, with the resultant increase in usable energy, altered the ability of the pituitary to release LH in response to exogenous oestrogen (Randel et al., 1982). The increased supply of nutrients may affect the gonadal tissues directly or affect the function of the hypothalamo-hypophysial system.

The results of the present study indicate that both progesterone priming and monensin supplementation in ewe lambs delayed and synchronized the LH surge occurring after exogenous FSH administration. Follicles in these ewes responded to the LH surge in a similar way to preovulatory follicles in mature, cyclic ewes, with proper luteinization and the formation of functional LCL, whereas the control animals had a higher proportion of short-lived corpora lutea.

We thank Eli Lilly, Sydney, for the supply of monensin; Dr J. Findlay for advice and facilities for the hCG binding site studies; Dr G. Martin for LH antibody; Professor G. Stabenfeldt for progesterone EIA components; Dr R. I. Cox and Dr M. Wong for testosterone antibody; and Dr K. Henderson for oestradiol antibody. This work was funded by the Hasanuddin University Development Fund and the Murdoch University Special Research Fund.

\section{References}

Armstrong, D.T. \& Opavsky, M.A. (1986) Biological characterization of a pituitary FSH preparation with reduced LH activity. Theriogenology 25, 135, Abstr.

Atkinson, S., Williamson, P., Kang, C.L. \& Carson, R.S. (1986) Steroid production and hCG binding by ram- induced ovarian follicles in seasonally anoestrous ewes. J. Reprod. Fert. 78, 403-412.

Baird, D.T. (1978) Pulsatile secretion of LH and ovarian estradiol in the follicular phase of the sheep estrous cycle. Biol. Reprod. 18, 359-364. 
Baird, D.T., Swanson, I.A. \& McNeilly, A.S. (1980) Relationship between LH, FSH and prolactin concentration and the secretion of androgens and estrogens by the pre-ovulatory follicle in the ewe. Biol. Reprod. 24, 1013-1025.

Bindon, B.M., Blanc, M.R., Pelletier, J., Tenqui, M. \& Thimonier, J. (1979) Peri-ovulatory gonadotrophin and ovarian steroid patterns in sheep of breeds with differing fecundity. J. Reprod. Fert. 55, 15-25.

Busmich, S.L., Randel, R.D., McCartor, M.M. \& Carroll, I.H. (1980) Effect of dietary monensin upon ovarian response following gonadotropin treatment in prepubertal heifers. J. Anim. Sci. 51, 692-696.

Carson, R.S., Findlay, J.K., Burger, H.G. \& Trounson, A.O. (1979) Gonadotropin receptors of the ovine ovarian follicle during follicular growth and atresia. Biol. Reprod. 21, 75-87.

Channing, C.P. (1978) Follicular non-steroidal regulators. In Ovarian Follicular and Corpus Luteum Function, pp. 327-337. Eds C. P. Channing, J. M. Marsh \& W. A. Sadler. Plenum Press, New York.

Cumming, I.A., Brown, J.M., Blockey de, M.A., Winfield, C.G., Baxter, R. \& Goding, J.R. (1971) Constancy of interval between $\mathrm{LH}$ release and ovulation in the ewe. J. Reprod. Fert. 24, 134-135.

England, B.G., Webb, R. \& Dahmer, M.K. (1981) Follicular steroidogenesis and gonadotropin binding to ovine follicles during the estrous cycle. Endocrinology 109, 881-887.

Foster, D.L. \& Ryan, K.D. (1979) Mechanisms governing onset of ovarian cyclicity at puberty in the lamb. Annls Biol. anim. Biochim. Biophys. 19, 1369-1380.

Foster, D.L., Lemons, J.A., Jaffe, R.B. \& Niswender, G.D. (1975) Sequential patterns of circulating LH and FSH in female sheep during early postnatal life through the first estrous cycles. Endocrinology 97, 985-994.

Haresign, W., Foxcroft, G.R. \& Lamming, G.E. (1983) Control of ovulation in farm animals. J. Reprod. Fert. 69, 383-395.

Harned, M.A. \& Casida, L.E. (1971) Local response to progesterone in the ewe ovary. J. Anim. Sci. 45, 328-334.

Hauger, R.L., Karsch, F.J. \& Foster, D.L. (1977) A new concept for control of the oestrous cycle of the ewe based on the temporal relationships between luteinizing hormone, estradiol and progesterone in peripheral serum and evidence that progesterone inhibits tonic LH secretion. Endocrinology 101, 807-817.

Horgan, E.D. \& Riley, W.J. (1974) Protein-binding assay for plasma testosterone after purification by column partition chromatography. Clin. Chem. 20, 430-435.

Martin, G.B., Oldham, C.M. \& Lindsay, D.R. (1980) Increased plasma $\mathrm{LH}$ levels in seasonally anovular Merino ewes following the introduction of rams. Anim. Reprod. Sci. 3, 125-132.

McCartor, M.M., Randel, R.D. \& Carroll, L.H. (1979) Dietary alteration of ruminal fermentation on efficiency of growth and onset of puberty in Brangus heifers. J. Anim. Sci. 48, 488-493.
McNatty, K.P., Baird, D.T., Bolton, A., Chambers, P., Corker, C.S. \& McLean, H. (1976) Concentration of oestrogens and androgens in human ovarian venous plasma and follicular fluid throughout the menstrual cycle. J. Endocr. 71, 77-85.

McNatty, K.P., Smith, M.S., Makris, A., Osatanondh, R. \& Ryan, K.J. (1979) The microenvironment of the human follicle: Interrelationships among the steroid levels in antral fluid, the population of granulosa cells and the status of the oocyte in vivo and in vitro. J. clin. Endocr. Metab. 49, 857-860.

McNatty, K.P., Gibb, M., Dobson, C. \& Thurley, D.C. (1981) Evidence that changes in luteinizing hormone secretion regulates the growth of the preovulatory follicle in the ewe. J. Endocr. 90, 375-389.

Munro, C. \& Stabenfeldt, G. (1984) Development of a micro-titre plate enzyme immunoassay (EIA) for the determination of progesterone. Endocrinology 101, 41-49.

Nie, N.H., Hull, C.H., Jenkins, J.G., Steinbrenner, K. \& Bent, D.H. (1975) Statistical Package for Social Sciences, 2nd edn. McGraw Hill, New York.

Oldham, C.M. \& Lindsay, D.R. (1979) Laparoscopy in the ewe: a photographic record of the ovarian activity of ewes experiencing normal or abnormal oestrous cycles. Anim. Reprod. Sci. 3, 119-124.

Randel, R.D., Rutter, L.M. \& Rhodes, R.C. (1982) Effect of monensin on the estrogen induced LH surge in prepubertal heifers. J. Anim. Sci. 54, 806-810.

Richardson, L.F., Raun, A.P., Potter, E.L., Cooley, C.O. \& Rathmacher, R.P. (1976) Effect of monensin on ruminal fermentation in vitro and in vivo. J. Anim. Sci. 43, 657-661.

Rodbard, D. (1974) Statistical quality and routine data processing for radioimmunoassays and immunoradiometric assays. Clin. Chem. 20, 1255-1270.

Snedecor, G.W. \& Cochran, W.G. (1967) Statistical Methods, 6th edn, pp. 91-119. Iowa State University Press, Ames.

Trounson, A.O., Willadsen, S.M. \& Moor, R.M. (1977) Reproductive function in prepubertal lambs: ovulation, embryo development and ovarian steroidogenesis. J. Reprod. Fert. 49, 69-75.

Tsonis, C.G., Quigg, H., Lee, V.W.K., Leversha, L., Trounson, A.O. \& Findlay, J.K. (1983) Inhibin in individual ovine follicles in relation to size and atresia. J. Reprod. Fert. 67, 83-90.

Webb, R. \& England, B.G. (1982a) Identification of the ovulatory follicle in the ewe: associated changes in follicular size, thecal and granulosa cell luteinizing hormone receptors, antral fluid steroids, and circulating hormone during the preovulatory period. Endocrinology 110,873-881.

Webb, R. \& England, B.G. (1982b) Relationship between $\mathrm{LH}$ receptor concentrations in thecal and granulosa cells and in vivo and in vitro steroid secretion by ovine follicles during the preovulatory period. J. Reprod. Fert. 66, 169-180.

Received 13 November 1986 